\title{
Spatial distribution patterns of Symplocos congeners in a subtropical evergreen broad-leaf forest of southern China
}

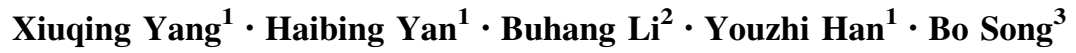

Received: 14 September 2016/ Accepted: 22 January 2017/Published online: 16 June 2017

(C) The Author(s) 2017. This article is an open access publication

\begin{abstract}
Studies on spatial distribution of congeneric species can supplement our understanding of species ecological processes. We analyzed population structure, spatial distribution, intra- and interspecific associations among six Symplocos tree species on a large (50 ha) plot in a subtropical, evergreen broad-leaf forest in southern China using spatial point pattern analysis methods. Our results suggested that the six Symplocos tree species were all clustered at small scales. The aggregation intensity of $S$. wikstroemiifolia with low abundance but relatively numerous large-diameter trees was much higher than that of the other five Symplocos species that occurred at high abundance but included few large-diameter trees. Spatial associations among the six congeners showed that 12 of 30 pairs were associated positively at small scales, and 13 of 30 pairs were unrelated. For species among different size
\end{abstract}

Project funding: This work was supported by National Natural Science Foundation of China (31470631 and 31670630), China Postdoctoral Science Foundation Grant (2013M530892) and Natural Science Foundation of Shanxi Province, China (2013011030-3).

The online version is available at http://www.springerlink.com

Corresponding editor: Zhu Hong.

Xiuqing Yang

Xiuqingy2002@126.com

1 College of Forestry, Shanxi Agricultural University, Taigu, Shanxi 030801, People's Republic of China

2 SYSU-Alberta Joint Lab for Biodiversity Conservation, State Key Laboratory of Biocontrol, School of Life Sciences, Sun Yat-sen University, Guangzhou 510275, People's Republic of China

3 Belle W. Baruch Institute of Coastal Ecology and Forest Science, Clemson University, Georgetown, SC 29442, USA classes, 79 of 120 pairs were not correlated, and 17 of 120 pairs were associated positively. These results showed insufficient evidence for interspecific competition and congeneric Symplocos species commonly coexist within subtropical plant communities. The spatial patterns of Symplocos species and their correlations changed with size (DBH) class and were simultaneously affected by spatial scales; the intensity of their aggregation and association decreased with increasing area of the sample plot.

Keywords Population structure - Spatial patterns . Spatial associations $\cdot$ Symplocos

\section{Introduction}

Species spatial distribution is the focus of attention by ecologists because of its importance to understanding ecological processes (Bunyavejchewin et al. 2003; Gao et al. 2014). Analyses of the spatial distributions of tree species and their associations shed light on the underlying ecological processes of species and can explain mechanisms that facilitate species coexistence, while contributing to the prediction of future forest community structures as determined by the underlying processes (Wiegand and Moloney 2004; Wiegand et al. 2007; Lan et al. 2012; Liao et al. 2015).

In many cases, comparative studies of the spatial distribution of tree species indicated that most conspecifics are clustered in space in naturally regenerated tropical (He et al. 1997; Condit et al. 2000) and temperate plant communities (Zhang et al. 2010). This phenomenon may be broadly attributed to three factors: (1) environmental factors such as habitat heterogeneity or niche differences (Harms et al. 2000; Queenborough et al. 2007; Inman- 
Narahari et al. 2014); (2) ecological processes of populations and communities such as dispersal limitation (Grubb 1977; Hubbell et al. 2001), seed deposition (Howe 1989), facilitation (Kikvidze et al. 2005), succession (Felinks and Wiegand 2008), and gap dynamics (Nagel et al. 2006); and (3) phylogenetic differences (Wang et al. 2013, 2015) and stochastic processes that build one cornerstone of neutral theory (Hubbell et al. 2001). Meanwhile, negative feedback responses to the clustered distribution of a species are important for explaining patterns of species coexistence such as negative density dependence (Seri and Shnerb 2015). Negative density dependence can arise because attacks by density-responsive natural enemies (such as host-specialized pathogens) increase disproportionately with local conspecific density (Janzen 1970; Connell 1971; Augspurger and Kelly 1984; Hammond and Brown 1998; Bell et al. 2006; Alvarez-Loayza and Terborgh 2011; Terborgh 2012; Bagchi et al. 2014) or because competition for natural resources (e.g., competition for seed dispersers) is more intense between conspecifics than heterospecifics (Jansen et al. 2014). These direct or indirect factors lead to "repulsion" between individuals or clusters (which induces self-thinning of the same species and decrease of recruitment in its neighborhood), thus increasing the chance that other species will occupy the vacated habitats and hence providing an important theoretical foundation to explain species coexistence (Comita et al. 2010; Bagchi et al. 2014; Jansen et al. 2014).

Previous comparative spatial pattern studies focused mostly on many species of different families/genera and occupying different habitats (He et al. 1997; Lan et al. 2012; Li et al. 2014). Nonpartitioning between habitat heterogeneity and phylogenetic difference has led to confusion about the relative importance of abiotic versus biotic factors on species spatial patterns and has hindered development of theory relating abiotic/biotic factors with patterns of distribution and coexistence. Research on congeners helps to exclude the ambiguous impact caused by phylogenetic differences (Bevill and Louda 1999; Lloyd et al. 2002; Swenson et al. 2006), and might elucidate factors that induce species distribution patterns such as weak scatter abilities (Cowling 2001; Simon and Hay 2003) or specialized habitat requirements (Queenborough et al. 2007). Therefore, analysis of the distributions of congeneric pairs in space offers special opportunities to explain species coexistence in a more scientific and rigorous manner ( $\mathrm{Li}$ et al. 2014). Alternatively, there exists much fiercer interspecific competition among congeneric species since they have similar phenotypic and ecological characteristics and probably use resources in similar ways (Ackerly and Donoghue 1998; Mooney et al. 2008), which, in principle, should discourage their coexistence (Webb et al. 2002; Mooney et al. 2008). Then, are these congenerics still mainly clustered? Are there differences between the spatial distributions of abundant versus scarce species, and what are the spatial associations among them? How do they coexist in the same communities? Zhang et al. (2010) analyzed the spatial pattern of congeneric Acer species in a temperate forest in northeastern China and revealed new species spatial patterns and coexistence. Their research focused on temperate forests but did not address plant communities at other latitudes.

In this study, we compared the spatial distribution and correlations of six sympatric Symplocos tree species in a 50-ha subtropical evergreen broad-leaf forest of southern China. A method of the pair-correlation function analysis was used to address the following questions: (1) How are these six congeners distributed in a multispecies southern subtropical forest? (2) Are there detectable differences in distribution patterns among them? (3) What is the correlation among these coexistent congeneric trees in terms of their spatial distribution within a community?

\section{Materials and methods}

\section{Study site}

Our study site, a subtropical evergreen broad-leaf forest at the Heishiding Nature Reserve, Guangdong Province, southern China $\left(23^{\circ} 26^{\prime} \mathrm{N}, 111^{\circ} 53^{\prime} \mathrm{E}\right)$ had a complex plant composition including 1070 species in 527 genera in 162 families. The dominant tree genera are Castanopis and Lithocarpus (Fagaceae), Machilus and Lindera (Lauraceae), Altingia chinensis (Hamamelidaceae), and Camellia (Theaceae). A subtropical moist monsoon climate characterizes this vegetation distribution area, and average annual temperature is $19.6^{\circ} \mathrm{C}$, with an average of $10.6{ }^{\circ} \mathrm{C}$ in January and $28.4{ }^{\circ} \mathrm{C}$ in July. Average annual precipitation is $1744 \mathrm{~mm}$, falling as rain from April to September. Average relative humidity is $80-85 \%$. Soil is classified as red acidic forest soil (Xu and Yu 2014; Shuai et al. 2014).

A 50 -ha $(1000 \times 500 \mathrm{~m})$ permanent forest plot was established in this evergreen broad-leaf forest in 2011 following the field protocol of the Center for Tropical Forest Science (CTFS) (Condit 1998). The first plot survey to record species presence and position, label trees, and record diameter at breast height (DBH) for trees of DBH $\geq 1 \mathrm{~cm}$ was completed in 2012. We recorded 273,000 living plants of 245 species, 160 genera, and 71 families. The five most abundant species were Xanthophyllum hainanense, Cryptocarya concinna, Litsea acuminate, Neolitsea phanerophlebia and Itea chinensis. There were 86 species (accounting for $35 \%$ of all species) represented by fewer than 50 plants. Average density and basal area of the stand was 5460 individuals and $39.02 \mathrm{~m}^{2}$ per hectare, 
respectively. Elevation range of the plot was from 435 to $698 \mathrm{~m}$, asl. Convexity at the $20 \mathrm{~m}$ scale range was from -24.53 to 17.63 . Slope span of the plot was from $6.89^{\circ}$ to $74.6^{\circ}$ (Fig. 1).

\section{Study species}

The genus Symplocos (Symplocaceae) contains about 318 species, most of which are native to the tropics and subtropics of Asia, Oceania and America (Fritsch et al. 2008). There are 77 Symplocos species reported for China (Editorial Board for Flora of China, Chinese Academy of Sciences 1974). These are mainly distributed in southwestern China, but some occur in southeastern China and only one species (Symplocos paniculata) in northeastern China. In our plot, individual Symplocos trees numbered 7500 but were not the most abundant. However, the genus Symplo$\cos$ was represented by more species (nine) than any other genus recorded in the plot. The nine species varied in habit from shade-tolerant understory shrubs to mid-story trees, and even some canopy species (the maximum height was $30 \mathrm{~m})$.

Six main Symplocos species were selected for analysis of their DBH structure, spatial patterns, and intra- and interspecific correlations. These were Symplocos adenophylla, S. anomala, S. congesta, S. lancifolia, S. laurina, and S. wikstroemiifolia (Fig. 2). The remaining three Symplocos species (S. denopus, S. pseudobarberina, S. stellaris) were not included in this study because of their low abundance.

All the six closely related Symplocos species with tryma are shade-tolerant, and their seeds are dispersed by birds. But their seed shape, size and season of production differ. S. wikstroemiifolia and S. adenophylla bear oval seeds of 6-12 mm long in July-August, S. anomala and S. congesta bear cylindrical seeds of 8-13 $\mathrm{mm}$ long in June-December (S. anomala) and January-February ( $S$. congesta), but $S$. lancifolia and $S$. laurina bear round seeds of 4-6 mm diameter long in June-December ( $S$. lancifolia) and

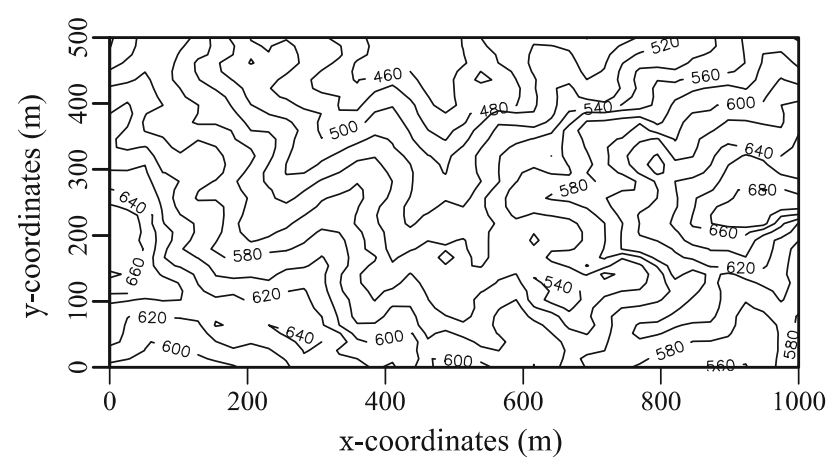

Fig. 1 Topography map of the plot at the Heishiding nature reserve, Guangdong Province, southern China
March-June (S. laurina) (Fig. 2). Moreover, S. anomala, S. congesta and $S$. lancifolia are understory species, $S$. wikstroemiifolia and $S$. adenophylla are midstory species, while $S$. laurina is a midstory or canopy species.

\section{Data analysis}

The pair-correlation function $\mathrm{g}(r)$, which combines univariate and bivariate statistics as one method of point pattern analysis, was used to explore the spatial distributions and correlations of the six Symplocos species at multiple scales (Wiegand and Moloney 2004; Wiegand et al. 2007, 2012). Univariate statistics were used to evaluate the spatial distribution of a single population and to decide whether the patterns of the six Symplocos species in different size classes were random, aggregated, or regular in space, and to describe the spatial scale range in which these patterns occurred. Bivariate statistics were used to evaluate spatial associations between two different populations and to determine whether intraspecific and interspecific correlations among species and DBH were positive, negative or unrelated in space.

In point pattern analysis, an aggregated distribution of species and positive interaction between two patterns at a given distance $r$ will be assumed, respectively, for univariate and bivariate analysis when $g(r)$ exceeds the upper confidence limit, while a regularly dispersed distribution and negative interaction will be assumed when $\mathrm{g}(r)$ fails to reach the lower confidence limit. Random dispersal and insignificant correlation are assumed when $g(r)$ lies within the confidence interval (Zhang et al. 2010).

To avoid error in estimating the spatial pattern of species, heterogeneous Poisson null models were used to explain probable environmental heterogeneity. In the model analysis, the emergence of all points is assumed independent of each other, the distribution of the points conform to an intensity function that changes with location (Wiegand and Moloney 2004; Wiegand et al. 2007). One intensity function was established for the pattern analysis in the univariate statistics based on the distribution of the six congeners. A second intensity function was established for the correlation analysis in the bivariate statistics by fixing the trees of the first species and randomizing the locations of the trees of the second species. A bandwidth of $30 \mathrm{~m}$ and a spatial resolution of $2 \mathrm{~m}$ were chosen for all analyses (Wiegand and Moloney 2004; Zhang et al. 2010). Here we analyzed all species pairs by testing not only species 1 versus species 2 but also species 2 versus species 1 of all pairs to avoid nonsymmetric interaction (Wiegand et al. 2007). We further analyzed the species pairs with DBH $\geq 5 \mathrm{~cm}$, pairs with DBH $<5 \mathrm{~cm}$, and pairs between DBH $\geq 5 \mathrm{~cm}$ and DBH $<5 \mathrm{~cm}$ (Cipriotti and Aguiar 2005; Zhang et al. 2010). 


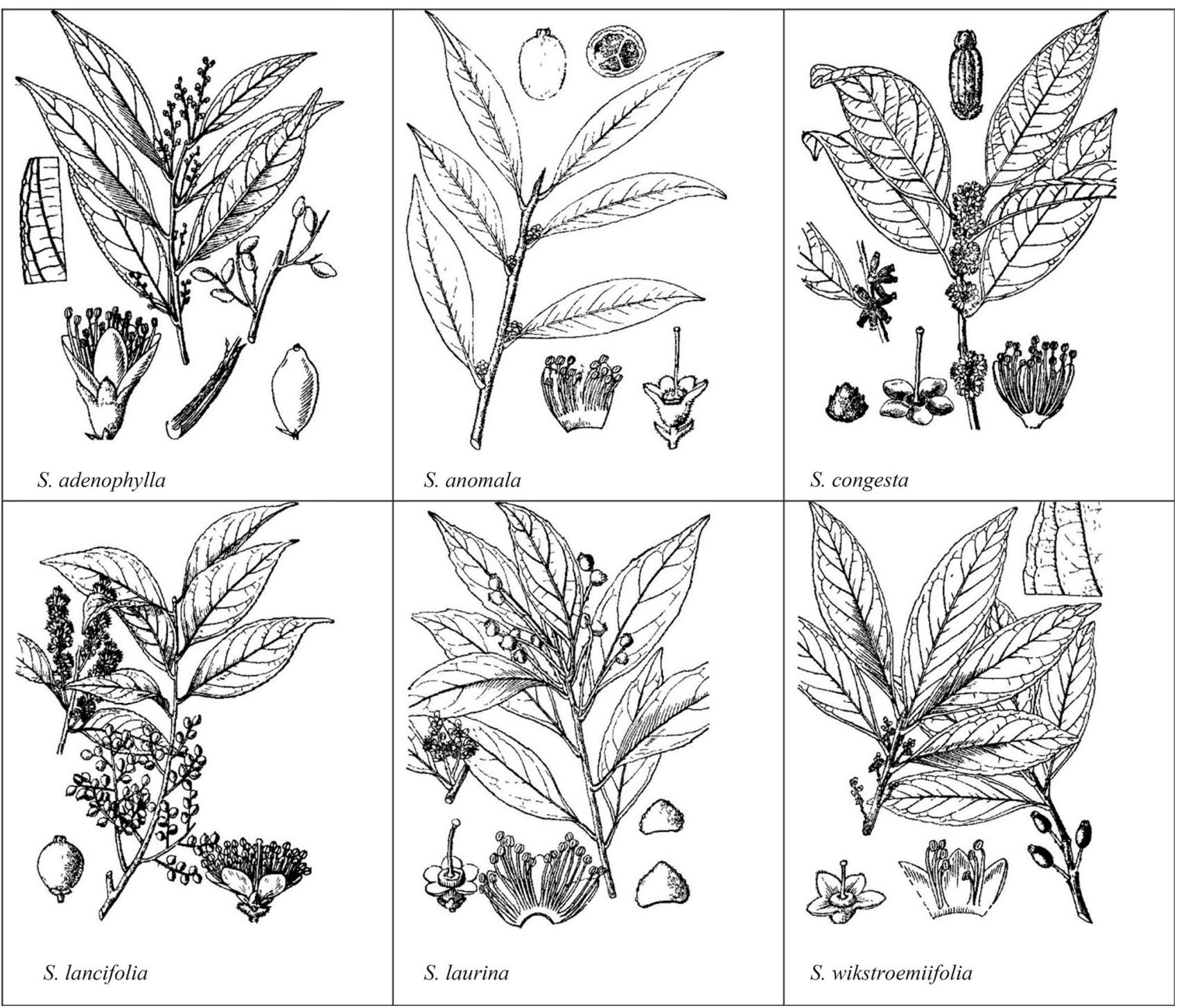

Fig. 2 Morphological traits of six Symplocos species. Source: Editorial Board for Flora of China, Chinese Academy of Sciences (1974)

Table 1 Population structure of six Symplocos species in a 50-ha subtropical evergreen broad-leaf forest in southern China

\begin{tabular}{|c|c|c|c|c|c|c|c|}
\hline \multirow[t]{2}{*}{ Species } & \multirow[t]{2}{*}{ Growth type } & \multicolumn{2}{|c|}{ Abundance (living) } & \multicolumn{2}{|c|}{ Basal area $\left(\mathrm{m}^{2} / \mathrm{ha}\right)$} & \multicolumn{2}{|c|}{ Mean DBH $(\mathrm{cm})$} \\
\hline & & WTB & WB & WTB & WB & WTB & WB \\
\hline S. adenophylla & Midstory & 1247 & 1351 & 0.0082 & 0.0085 & 4.9277 & 4.8134 \\
\hline S. wikstroemiifolia & Midstory & 238 & 254 & 0.0089 & 0.0094 & 13.6601 & 13.6188 \\
\hline S. congesta & Understory & 1305 & 1403 & 0.0062 & 0.0065 & 3.9368 & 3.8693 \\
\hline S. laurina & Midstory/canopy & 1749 & 1964 & 0.0270 & 0.0318 & 6.5131 & 6.7961 \\
\hline S. lancifolia & Understory & 1171 & 1280 & 0.0055 & 0.0061 & 3.9924 & 4.0137 \\
\hline S. anomala & Understory & 933 & 1118 & 0.0036 & 0.0043 & 3.6002 & 3.6071 \\
\hline
\end{tabular}

$W T B$ is abundance without branches, $W B$ is abundance with branches

Data were processed using the grid-based estimators in the Programita software package (Wiegand and Moloney 2004). The spatial scale of $20 \mathrm{~m}$ was adopted for the goodness-of-fit $(\mathrm{GoF})$ test, and results were further analysed when $p \leq 0.05$. Confidence intervals $(99 \%)$ were determined using the extreme values of $g(r)$ derived from 199 Monte Carlo simulations of the null model. 


\section{Results}

\section{Population structure}

Individual plants of the six selected Symplocos species ranged in number from 254 (S. wikstroemiifolia) to 1964 (S. laurina, Table 1). The abundance of $S$. wikstroemiifolia was lowest of the six species. Abundance ranked in decreasing order as: S. laurina (1964) $>S$. congesta
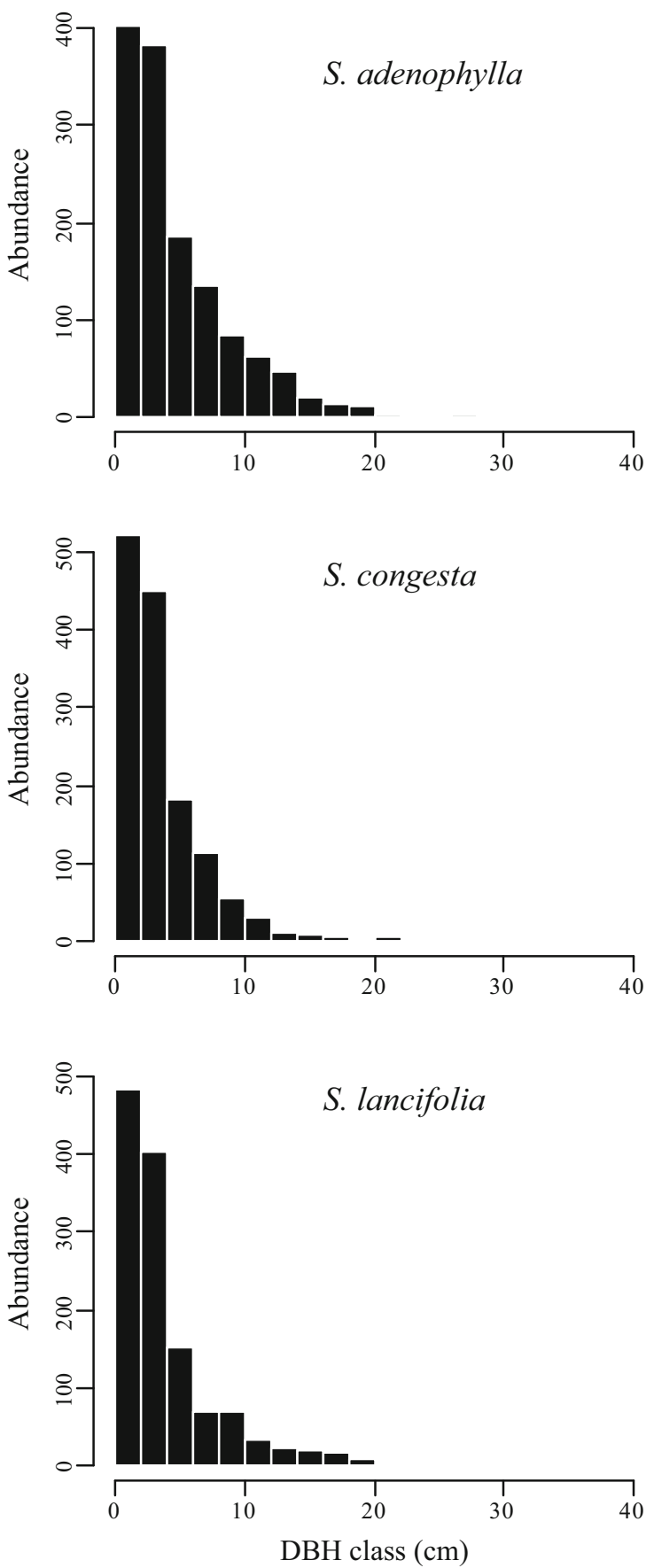

$(1403)>S . \quad$ adenophylla $\quad(1351)>S . \quad$ lancifolia $(1280)>S$. anomala (1118). S. laurina and S. anomala had the most branches, while $S$. wikstroemiifolia had the fewest. Total basal area of $S$. laurina was significantly larger than that of the other five species, and mean DBH of S. wikstroemiifolia was notably largest.

The five species with abundance over 1000 (S. adenophylla, S. congesta, S. lancifolia, S. anomala, and S. laurina) had distinct L-shaped distributions, while $S$.
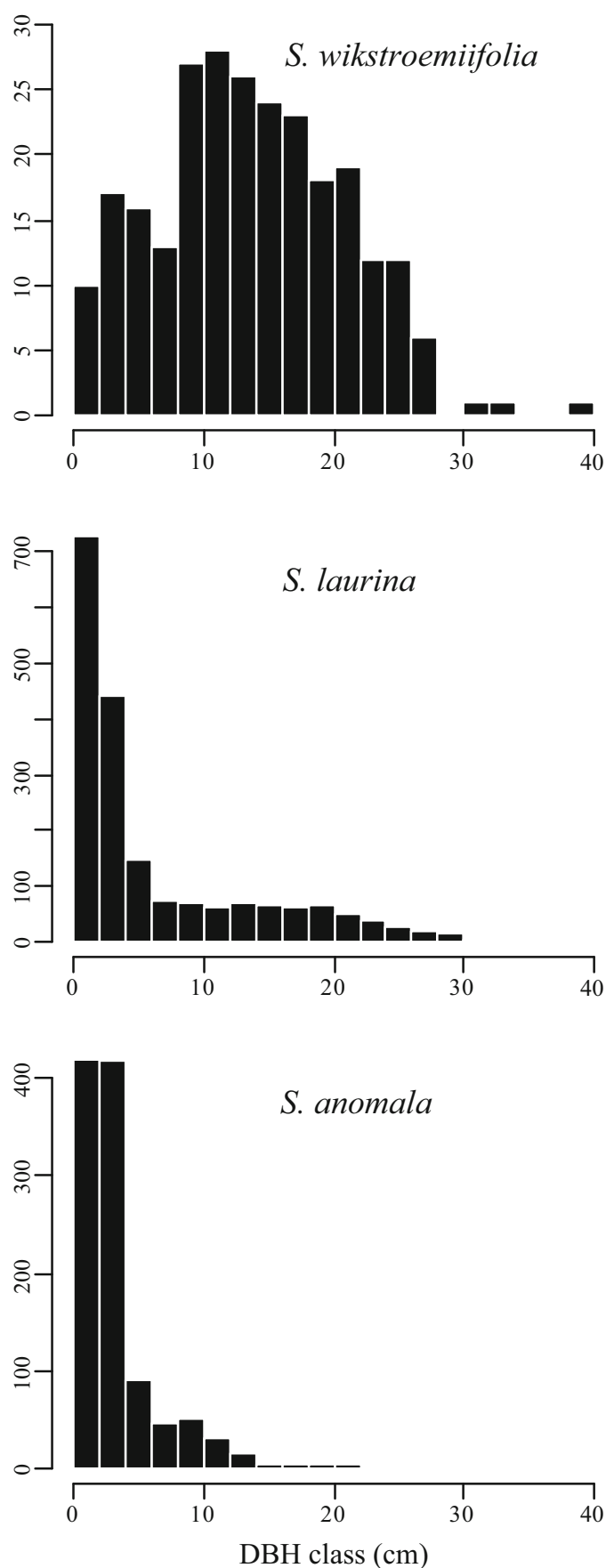

Fig. 3 Abundance by DBH size of class of the six Symplocos species in the study plot 
wikstroemiifolia with few individuals showed a unimodalshaped size class distribution (Fig. 3). Few individuals had a DBH $>10 \mathrm{~cm}$ among the high-abundance species $(S$. adenophylla, S. congesta, S. lancifolia, S. anomala, and $S$. laurina). There were relatively more large specimens of the low-abundance species $S$. wikstroemiifolia compared with the other species.

\section{Spatial patterns}

The spatial distributions of the six Symplocos tree species differed. S. adenophylla was mainly distributed in the middle of the plot from north to south. S. laurina was centralized in the northwestern corner and southern part
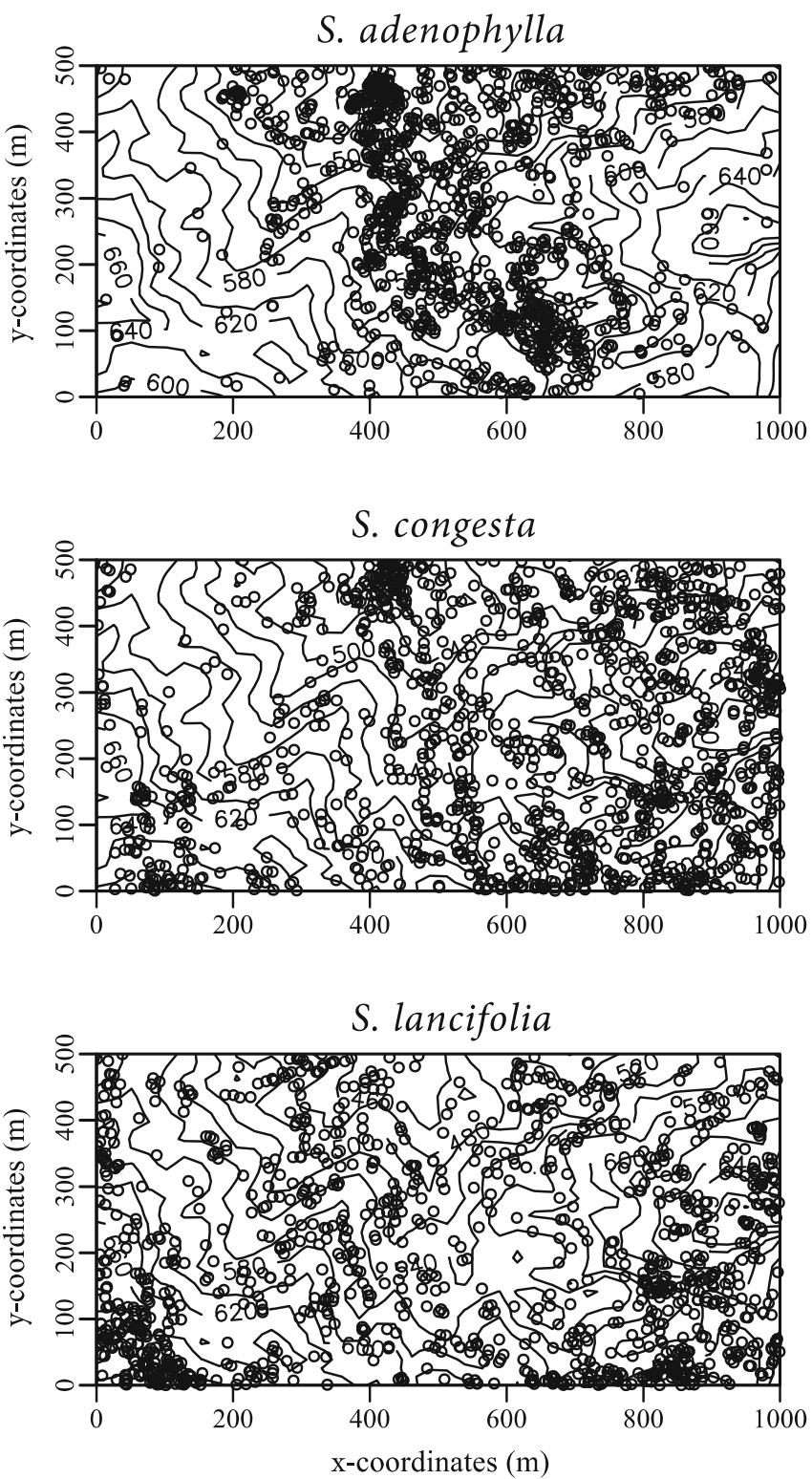

Fig. 5 Univariate point pattern analysis of six Symplocos species. (The insertions indicate the point pattern analysis of two size classes (DBH $<5 \mathrm{~cm}$ and $\mathrm{DBH} \geq 5 \mathrm{~cm}$ ). Black lines indicate g11( $r)$ function; dotted lines indicate the upper and lower limits of the $99 \%$ confidence interval. Points above the upper limits indicate aggregation distribution, within the intervals random, and below the lower limits regular. The $99 \%$ confidence level were calculated using the highest and the lowest values of $\mathrm{g} 11(\mathrm{r})$ derived from 199 Monte Carlo simulations of the heterogeneous Poisson null model with bandwidth $h=30 \mathrm{~m}$; ring width for estimation of the pair-correlation function was $4 \mathrm{~m}$; cell size was $2 \times 2 \mathrm{~m}$ )

of the plot. S. lancifolia and S. anomala were spread out nearly over the entire plot. $S$. congesta occurred everywhere but the northeastern corner. S. wikstroemiifolia was only found in the southwestern corner of the plot (Fig. 4).
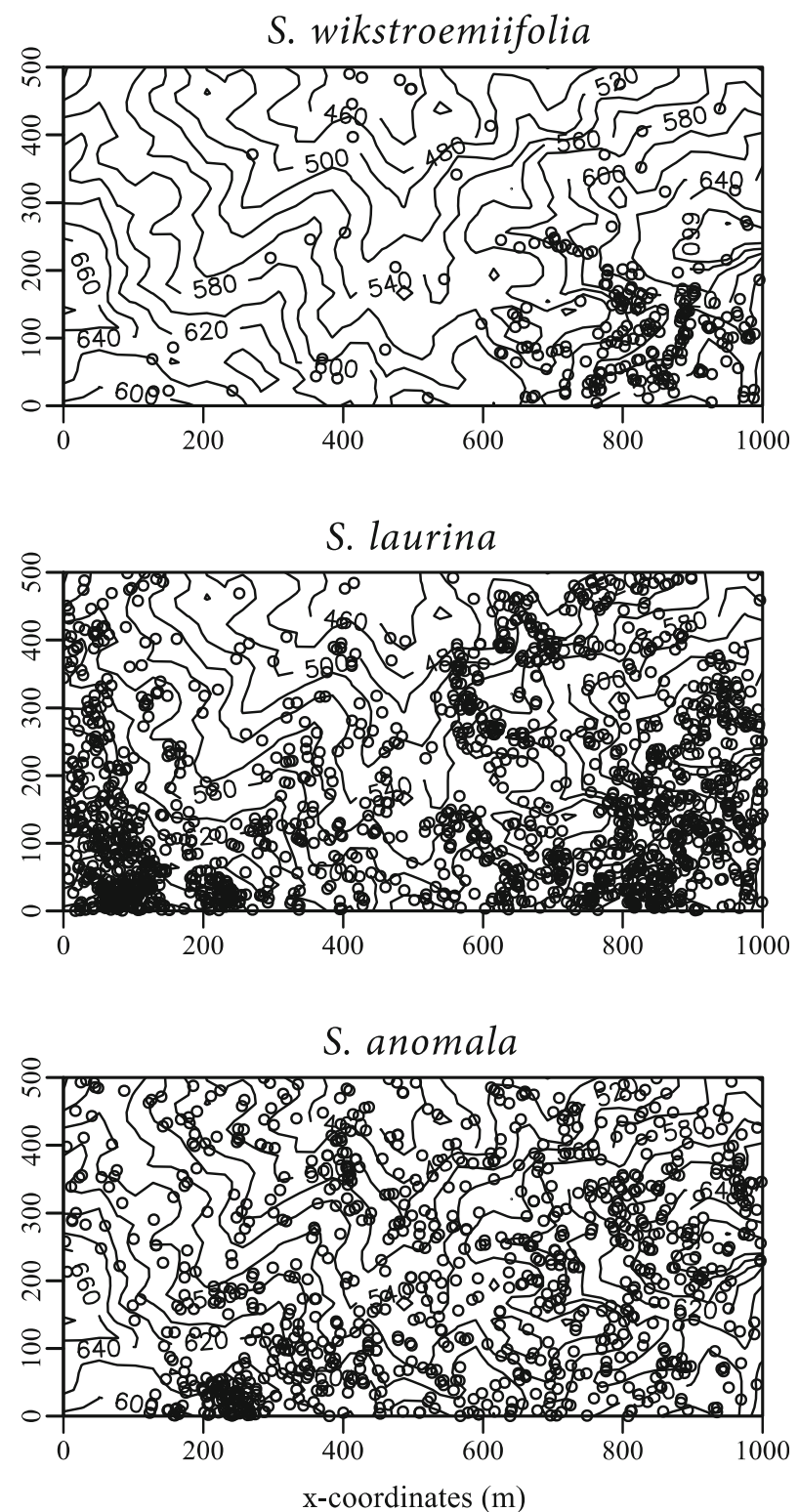

Fig. 4 Spatial distribution of six Symplocos species in relation to the topography of the study plot 

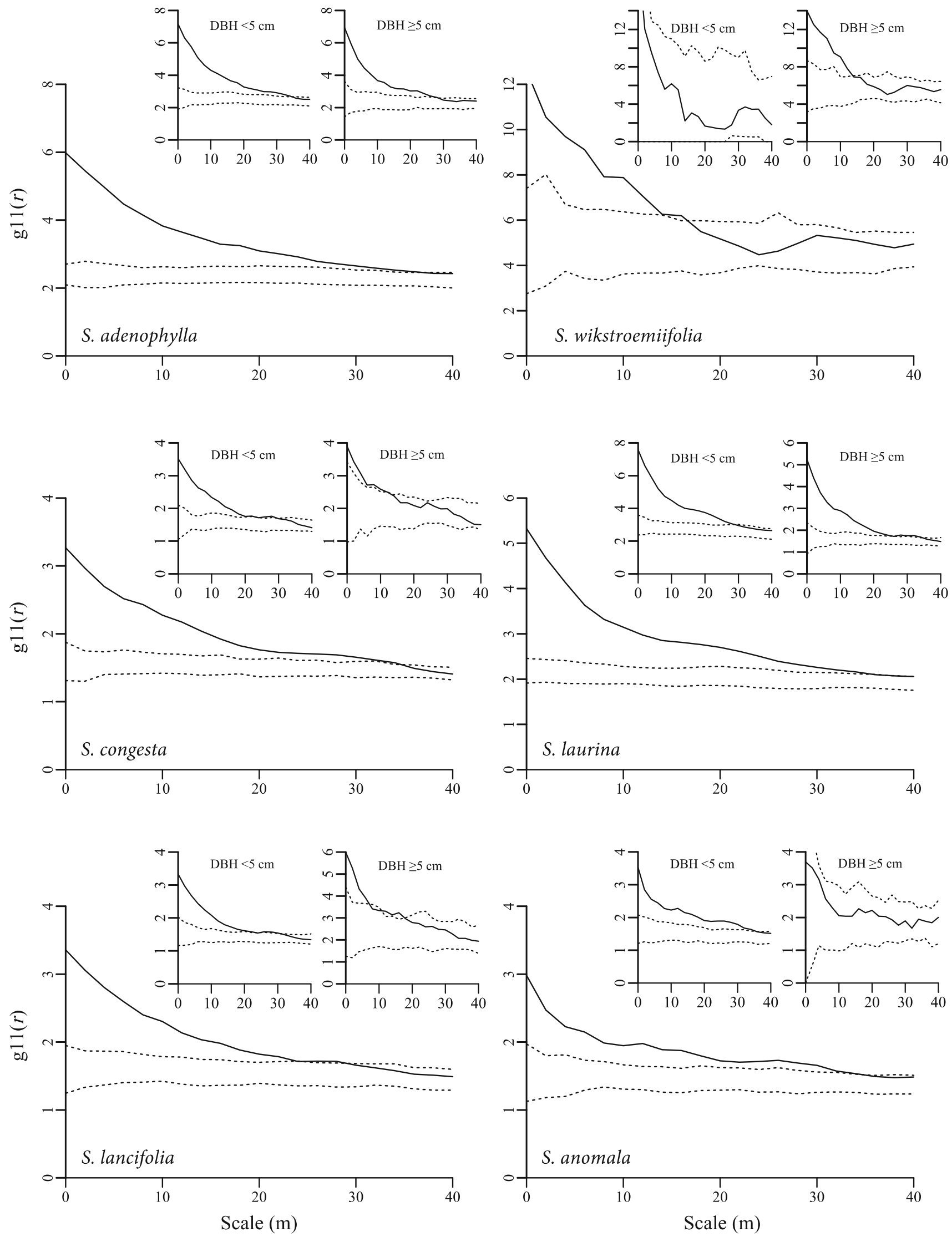
The six congeners were notably aggregated (Fig. 4). The GoF test indicated deviation from the Poisson null model (at 0-20 m scale range). Two species (S. adenophylla and S. laurina) had a high cluster intensity at $0-35 \mathrm{~m}$ scale range. The other three species also occurred in aggregated distributions at $0-35 \mathrm{~m}$ ( $S$. congesta and $S$. anomala) or 0-30 m (S. lancifolia) scale ranges, but were less aggregated than S. adenophylla and S. laurina (Fig. 5). S. wikstroemiifolia was more highly aggregated than the other five species (Figs. 4, 5). The degree of aggregation of all six species decreased as the scale increased, which conformed to their natural distributions in the plot (Fig. 4).

Five mid-story species (S. adenophylla, S. congesta, $S$. laurina, S. lancifolia, and S. anomala) had individuals with DBH $<5 \mathrm{~cm}$, and they all notably aggregated at 0-20 m scale range. Among these species, $S$. adenophylla and $S$. laurina had a much higher clustering intensity than that of the other three species (Fig. 5). For individuals with DBH $\geq 5 \mathrm{~cm}$, two species ( $S$. adenophylla and S. laurina) were notably aggregated at $0-20 \mathrm{~m}$ scale range, while $S$. wikstroemiifolia and $S$. congesta were aggregated at $0-13 \mathrm{~m}$ but random at $>13 \mathrm{~m}$ scale range. Additionally, $S$. lancifolia was aggregated at $0-7$ and $10-17 \mathrm{~m}$, and random at $7-10$ and $>17 \mathrm{~m}$ scale ranges; $S$. anomala was randomly distributed at all study scales (Fig. 5).

\section{Spatial associations}

There were positive associations for 12 pairs of species and negative associations for five pairs at the small scale range (Table 2). Ten of 12 pairs with positive associations proved symmetrical in S. lancifolia and S. wikstroemiifolia, $S$. laurina and $S$. wikstroemiifolia, $S$. congesta and $S$. wikstroemiifolia, S. congesta and S. lancifolia, and S. lancifolia and S. laurina. S. lancifolia and S. wikstroemiifolia were associated positively at the $0-4 \mathrm{~m}$ scale range, $S$. laurina and S. wikstroemiifolia at 0-6 $\mathrm{m}, S$. congesta and $S$. wikstroemiifolia at $0-8 \mathrm{~m}, S$. congesta and S. lancifolia at $0-14 \mathrm{~m}$, and $S$. lancifolia and $S$. laurina at $0-18 \mathrm{~m}$ scale range. $S$. adenophylla had a positive association with $S$. congesta at $0-2 \mathrm{~m}$ scale range, and $S$. lancifolia had a positive association with $S$. adenophylla at $0-2 \mathrm{~m}$ scale range. Five pairs with negative associations proved symmetrical in S. adenophylla and S. laurina, S. adenophylla and $S$. wikstroemiifolia at scales of the entire study plot. $S$. adenophylla and S. lancifolia were negatively correlated at all scales in the entire study plot. The remaining 13 pairs had no significant spatial associations.

The spatial correlations between large DBH $(\geq 5 \mathrm{~cm})$ plants and small DBH $(<5 \mathrm{~cm})$ plants of the same species were further tested. Eight of 12 species pairs had positive associations at $0-18 \mathrm{~m}$ scale range, and none were negatively associated at any scale (Fig. 6). For the correlations for different species pairs with large DBH $(\geq 5 \mathrm{~cm}), 8$ of 30 species pairs had symmetrical negative associations with $S$. adenophylla and 4 other species ( $S$. anomala, $S$. lancifolia, S. laurina and S. wikstroemiifolia), 4 of 30 species pairs had symmetrical positive associations among $S$. lancifolia and 2 other species ( $S$. congesta and $S$. wikstroemiifolia) at the small scale $(<4 \mathrm{~m})$, and the remaining 18 species pairs were not correlated (Fig. 6). For the correlations of different species pairs with small DBH $(<5 \mathrm{~cm})$, 21 of 30 species pairs were not correlated, five species pairs (S. lancifolia symmetrically vs $S$. congesta, S. lancifolia symmetrically vs $S$. laurina, $S$. congesta vs $S$. adenophylla) had positive associations at small scales, and four species pairs ( $S$. adenophylla symmetrically vs $S$. lancifolia, $S$. adenophylla symmetrically vs. S. laurina) had negative associations (Fig. 6). For the correlations between large DBH $(\geq 5 \mathrm{~cm})$ individuals and small DBH $(<5 \mathrm{~cm})$ individuals of different species, six of 60 species pairs were positively associated at small scales and 14 of 60 species pairs were negatively associated at $0-20 \mathrm{~m}$ scale range. The remaining 40 species pairs were not notably associated (Fig. 6).

\section{Discussion}

The distribution patterns of tree species in space provide fundamental information for comprehending underlying ecological process and species coexistence mechanisms ( $\mathrm{Li}$ et al. 2014). Similar species occupying one ecological area theoretically repel sibling species because of the similarity between their strategies for resource use. Thus, obstacles to coexistence often occur among congenerics. Our analysis of the spatial associations among six congeners found that 12 of 30 pairs were associated positively at small scales, and 13 of 30 pairs were unrelated. For species with different size classes, 79 of 120 pairs were not correlated, and 17 of 120 pairs were associated positively. These results suggest that coexistence of Symplocos species within subtropical plant communities is common and that interspecific competition among them is not very common. Consistent co-occurrence patterns of congeneric tree species were reported for other plant communities (Zhang et al. 2010; $\mathrm{Li}$ et al. 2014). What determines the relative distribution of congeneric species in a community? Previous studies suggested that divergence of traits within a genus can reduce niche overlap and relax competition, thus permitting the co-occurrence of congeners (Beltrán et al. 2012). The six Symplocos species varied in habit from shade-tolerant understorey shrubs to mid-storey trees, and even to canopy trees (maximum height of $30 \mathrm{~m}$ ). The distinct functional traits characteristic of these growth 


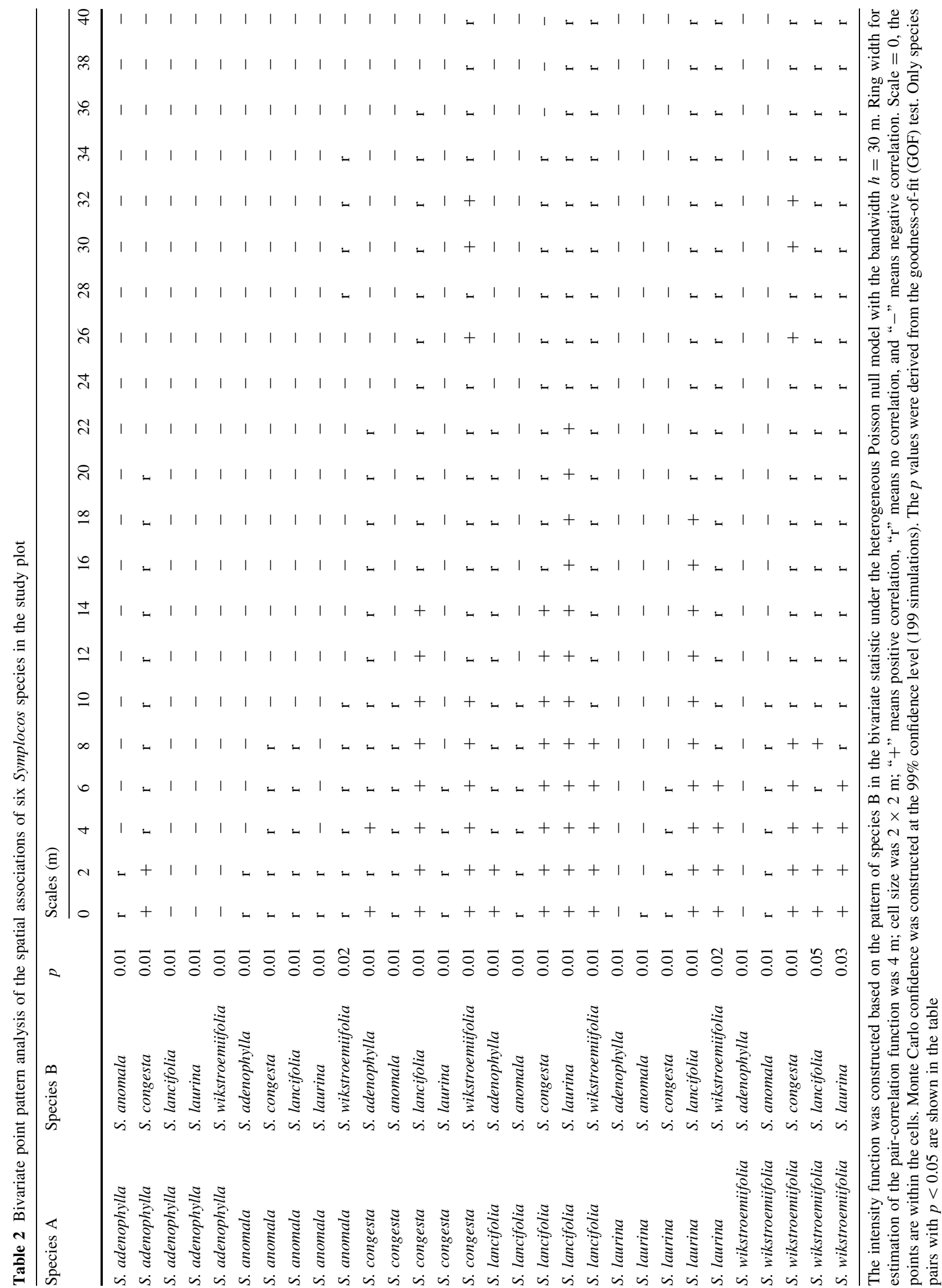



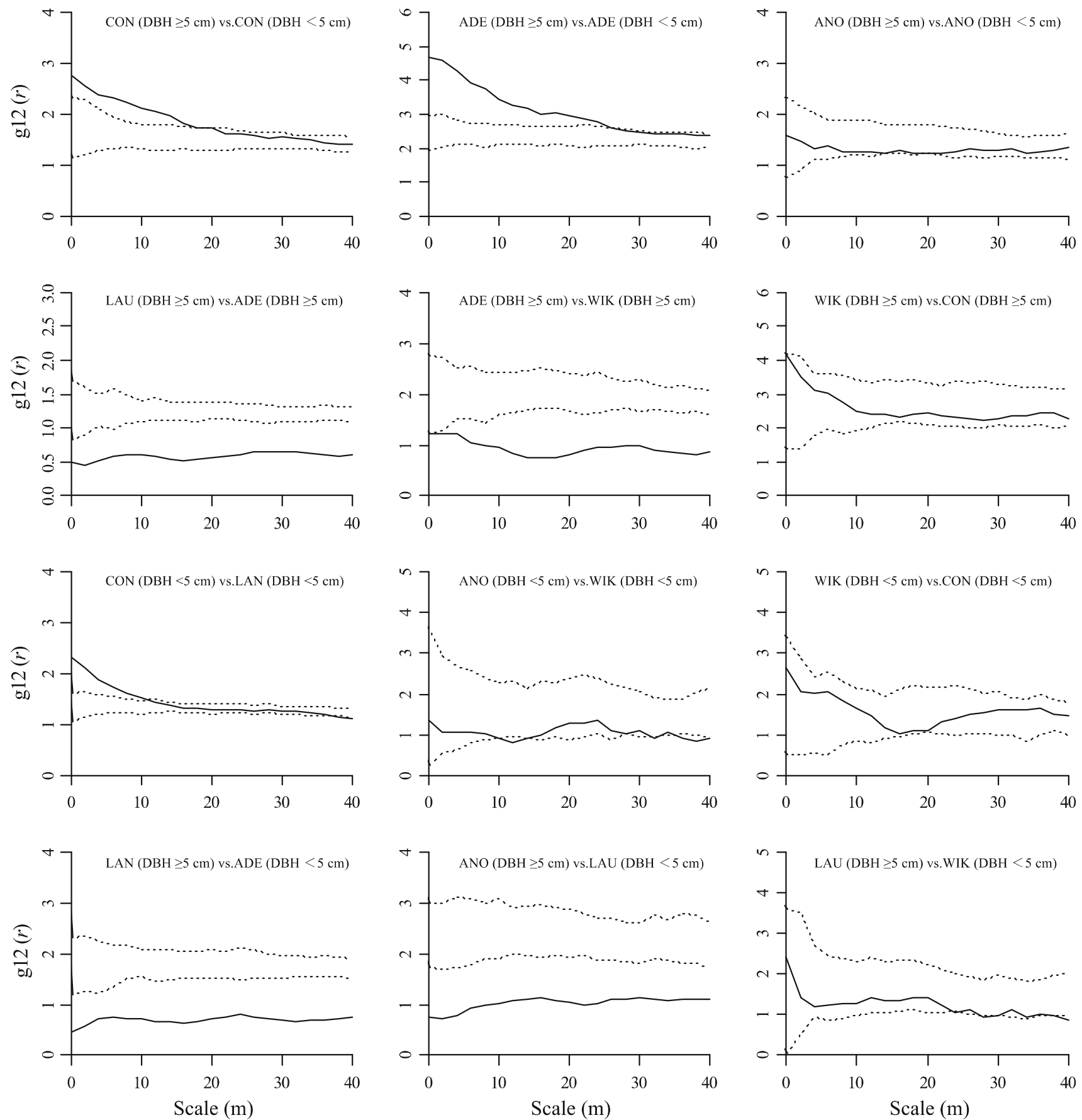

Fig. 6 Bivariate point pattern analysis examples for intra- and interspecies associations among two size classes (DBH $<5 \mathrm{~cm}$ and $\mathrm{DBH} \geq 5 \mathrm{~cm}$ ) of six Symplocos species. CON: $S$. congesta, ADE: $S$. adenophylla, ANO: S. anomala, LAU: S. laurina, WIK: S. wikstroemiifolia, LAN: S. lancifolia. Black lines indicate g12(r) function;

habits might explain the coexistence of Symplocos species within this subtropical forest.

Specialized habitat is also an important impact factor contributing to the coexistence of congeneric species (Davies et al. 1998). In our plot, elevation varied from 435.4 to $698.4 \mathrm{~m}$ asl. These congeneric species distributed dotted lines indicate the upper and lower limits of the $99 \%$ confidence interval. Points above the upper limits indicate a positive correlation, within the intervals indicate no correlation, and below the lower limits negative correlation

in different parts of the heterogeneous topography. Hence, we suggest that topographical differences may contribute to species traits divergence and thus maintain the coexistence of species within a genus.

Significant difference of size (DBH) class structure distinguished the congeners. S. wikstroemiifolia with few 
individuals had a unimodal shaped size-class structure with many large trees. The five other congeners were more abundant and had a distinct L-shaped size-class structure with few large individuals. The distribution patterns of some species changed with size-class. For example, $S$. anomala at DBH $<5 \mathrm{~cm}$ had significant aggregation at small scales. In contrast, $S$. anomala at $\mathrm{DBH} \geq 5 \mathrm{~cm}$ was randomly distributed at all study scales. For small plants of DBH $<5 \mathrm{~cm}$, the degree of aggregation of $S$. adenophylla and $S$. laurina was much higher than that of the other congeners, but for large individuals of DBH $\geq 5 \mathrm{~cm}, S$. wikstroemiifolia had the highest degree of aggregation of all six congeners. The spatial associations between some species pairs also varied by size-class. For example, the GoF test detected a symmetrically positive association between small-small trees at scales of $0-10 \mathrm{~m}$, but no correlation between large-large trees or large-small trees. The observed size-dependent changes in the distribution pattern of the six congeners and their associations are possibly due to the changes of functional traits of species with increasing tree size. Because tree functional traits such as stem diameter, leaf mass, specific leaf area, and $\mathrm{N} / \mathrm{P}$ ratio in leaf usually have underlying effects on species survival and competitive ability, such traits typically vary with tree size (Iida et al. 2014). Moreover, the spatial patterns of the congeners and their associations were found to change with spatial scales, and the intensity of aggregation and association decreased as scaling increased as a whole.

Acknowledgements We are grateful to Buhang Li in SYSU-Alberta Joint Lab for Biodiversity Conservation, State Key Laboratory of Biocontrol, School of Life Sciences, Sun Yat-sen University who provided insightful and constructive comments which greatly improved the manuscript. This work was conducted while Xiuqing Yang was visiting Belle W. Baruch Institute of Coastal Ecology and Forest Science, Clemson University in 2016.

Open Access This article is distributed under the terms of the Creative Commons Attribution 4.0 International License (http://crea tivecommons.org/licenses/by/4.0/), which permits unrestricted use, distribution, and reproduction in any medium, provided you give appropriate credit to the original author(s) and the source, provide a link to the Creative Commons license, and indicate if changes were made.

\section{References}

Ackerly DD, Donoghue MJ (1998) Leaf size, sapling allometry, and Corner's rules: phylogeny and correlated evolution in maples (Acer). Am Nat 152:767-791

Alvarez-Loayza P, Terborgh J (2011) Fates of seedling carpets in an Amazonian floodplain forest: Intra-cohort competition or attack by enemies? J Ecol 99:1045-1054

Augspurger CK, Kelly CK (1984) Pathogen mortality of tropical tree seedlings: experimental studies of the effects of dispersal distance, seedling density, and light conditions. Oecologia 61:211-217
Bagchi R, Gallery RE, Gripenberg S, Gurr SJ, Narayan L, Addis CE, Freckleton RP, Lewis OT (2014) Pathogens and insect herbivores drive rainforest plant diversity and composition. Nature 506:85-88

Bell T, Freckleton RP, Lewis OT (2006) Plant pathogens drive density-dependent seedling mortality in a tropical tree. Ecol Lett 9:569-574

Beltrán E, Valiente-Banuet A, VerdúVerd M (2012) Trait divergence and indirect interactions allow facilitation of congeneric species. Ann Bot 110:1369-1376

Bevill RL, Louda SM (1999) Comparisons of related rare and common species in the study of plant rarity. Conserv Biol 13:493-498

Bunyavejchewin S, LaFrankie JV, Baker PJ, Kanzaki M, Ashton PS, Yamakura T (2003) Spatial distribution patterns of the dominant canopy dipterocarp species in a seasonal dry evergreen forest in western Thailand. For Ecol Manag 175:87-101

Cipriotti PA, Aguiar MR (2005) Effects of grazing on patch structure in a semi-arid two-phase vegetation mosaic. J Veg Sci 16:57-66

Comita LS, Muller-Landau HC, Aguilar S, Hubbell SP (2010) Asymmetric density dependence shapes species abundances in a tropical tree community. Science 329:330-332

Condit R (1998) Tropical forest census plots: methods and results from Barro Colorado Island, Panama and a Comparison with other plots. Springer, Berlin, pp 17-19

Condit R, Ashton PS, Baker PJ, Bunyavejchewin S, Gunatilleke S, Gunatilleke N, Hubbell SP, Foster RB, Itoh A, LaFrankie JV, Lee HS, Losos E, Manokaran N, Sukumar R, Yamakura T (2000) Spatial patterns in the distribution of common and rare tropical tree species. Science 288:1414-1418

Connell JH (1971) On the role of natural enemies in preventing competitive exclusion in some marine animals and in rain forest trees. In: Den Boer PJ, Gradwell GR (eds) Dynamics of numbers in populations. Center for Agricultural Publication and Documentation, Wageningen, pp 298-312

Cowling RM (2001) Endemism. In: Levin SA (ed) Encyclopedia of biodiversity. Academic Press, San Diego, pp 497-507

Davies SJ, Palmiotto PA, Ashton PS, Lee HS, Lafrankie JV (1998) Comparative ecology of 11 sympatric species of Macaranga in Borneo: tree distribution in relation to horizontal and vertical resource heterogeneity. J Ecol 86:662-673

Editorial Board for Flora of China, Chinese Academy of Sciences (1974) The sixtieth volumes of Flora of China (second fascicule). Science Press, Beijing, pp 1-8 (in Chinese)

Felinks B, Wiegand T (2008) Exploring spatiotemporal patterns in early stages of primary succession on former lignite mining sites. J Veg Sci 19:267-276

Fritsch PW, Kelly LM, Wang Y, Almeda F, Kriebel R (2008) Revised infrafamilial classification of Symplocaceae based on phylogenetic data from DNA sequences and morphology. Taxon 57:823-852

Gao M, Wang X, Wang D (2014) Species spatial distribution analysis using nearest neighbor methods: aggregation and self-similarity. Ecol Res 29:341-349

Grubb PJ (1977) Maintenance of species-richness in plant communities: the importance of the regeneration niche. Biol Rev 52:107-145

Hammond DS, Brown VK (1998) Disturbance, phenology and lifehistory characteristics: factors influencing distance/density-dependent attack on tropical seeds and seedlings. In: Dynamics of tropical communities: the 37th symposium of the British Ecological Society, Cambridge University, pp 51-78

Harms KE, Wright SJ, Calderon O, Hernandez A, Herre EA (2000) Pervasive density-dependent recruitment enhances seedling diversity in a tropical forest. Nature 404:493-495 
He F, Legendre P, LaFrankie JV (1997) Distribution patterns of tree species in a Malaysian tropical rain forest. J Veg Sci 8:105-114

Howe HF (1989) Scatter-and clump-dispersal and seedling demography: hypothesis and implications. Oecologia 79:417-426

Hubbell SP, Ahumada JA, Condit R, Foster RB (2001) Local neighborhood effects on long-term survival of individual trees in a neotropical forest. Ecol Res 16:859-875

Iida Y, Kohyama T, Swenson NG, Su SH, Chen CT, Chiang JM, Sun IF (2014) Linking functional traits and demographic rates in a subtropical tree community: the importance of size dependency. J Ecol 102:641-650

Inman-Narahari F, Ostertag R, Asner GP, Cordell S, Hubbell SP, Sack L (2014) Trade-offs in seedling growth and survival within and across tropical forest microhabitats. Ecol Evol 4:3755-3767

Jansen PA, Visser MD, Wright SJ, Rutten G, Muller-Landau HC (2014) Negative density dependence of seed dispersal and seedling recruitment in a Neotropical palm. Ecol Lett 17:1111-1120

Janzen DH (1970) Herbivores and the number of tree species in tropical forests. Am Nat 104:501-528

Kikvidze Z, Pugnaire FI, Brooker RW, Choler P, Lortie CJ, Michalet R, Callaway RM (2005) Linking patterns and processes in alpine plant communities: a global study. Ecology 86:1395-1400

Lan G, Getzin S, Wiegand T, Hu Y, Xie G, Zhu H, Cao M (2012) Spatial distribution and interspecific associations of tree species in a tropical seasonal rain forest of China. PLoS ONE 7:e46074

Li L, Ye WH, Wei SG, Lian JY, Huang ZL (2014) Spatial Patterns and Associations between Species Belonging to Four Genera of the Lauraceae Family. PLoS ONE 9:e111500

Liao J, Bogaert J, Nijs I (2015) Species interactions determine the spatial mortality patterns emerging in plant communities after extreme events. Sci Rep 5:11229

Lloyd KM, Lee WG, Wilson JB (2002) Competitive abilities of rare and common plants: comparisons using Acaena (Rosaceae) and Chionochloa (Poaceae) from New Zealand. Conserv Biol 16:975-985

Mooney KA, Jones P, Agrawal AA (2008) Coexisting congeners: demography, competition, and interactions with cardenolides for two milkweed-feeding aphids. Oikos 117:450-458

Nagel TA, Svobodab M, Diacia J (2006) Regeneration patterns after intermediate wind disturbance in an old-growth Fagus-Abies forest in southeastern Slovenia. For Ecol Manag 226:268-278
Queenborough SA, Burslem DFRP, Garwood NC, Valencia R (2007) Habitat niche partitioning by 16 species of Myristicaceae in Amazonian Ecuador. Plant Ecol 192:193-207

Seri E, Shnerb NM (2015) Spatial patterns in the tropical forest reveal connections between negative feedback, aggregation and abundance. J Theor Biol 380:247-255

Shuai F, Wang Y, Yu S (2014) Density dependence in forests is stronger in tropical and subtropical climates among closely related species. Ecography 37:659-669

Simon MF, Hay JD (2003) Comparison of a common and rare species of Mimosa (Mimosaceae) in Central Brazil. Austral Ecol 28:315-326

Swenson NG, Enquist BJ, Pither J, Thompson J, Zimmerman J (2006) The problem and promise of scale dependency in community phylogenetics. Ecology 87:2418-2424

Terborgh J (2012) Enemies maintain hyperdiverse tropical forests. Am Nat 179:303-314

Wang X, Swenson NG, Wiegand T, Wolf AT, Howe R, Lin F, Ye J, Yuan Z, Shi S, Bai X, Xing D, Hao Z (2013) Phylogenetic and functional diversity area relationship in two temperate forests. Ecography 36:883-893

Wang X, Wiegand T, Swenson NG, Wolf AT, Howe RW, Hao Z, Lin F, Ye J, Yuan Z (2015) Mechanisms underlying local functional and phylogenetic beta diversity in two temperate forests. Ecology 96:1062-1073

Webb CO, Ackerly DD, McPeek MA, Donoghue MJ (2002) Phylogenies and community ecology. Annu Rev Ecol Syst 33:475-505

Wiegand T, Moloney KA (2004) Rings, circles, and null-models for point pattern analysis in ecology. Oikos 104:209-229

Wiegand T, Gunatilleke S, Gunatilleke N (2007) Species associations in a heterogeneous Sri Lankan dipterocarp forest. Am Nat 170:e77-e95

Wiegand T, He F, Hubbell SP (2012) A systematic comparison of summary characteristics for quantifying point patterns in ecology. Ecography 35:1-12

Xu M, Yu S (2014) Elevational variation in density dependence in a subtropical forest. Ecol Evol 4:2823-2833

Zhang J, Song B, Li BH, Ye J, Wang XG, Hao ZQ (2010) Spatial pattern and associations of six congeneric species in an oldgrowth temperate forest. Acta Oecol 36:29-38 